\title{
Egypt's Exchange Rate Regime Policy after the Float
}

\author{
Ali A. Massoud ${ }^{1,2} \&$ Thomas D. Willett ${ }^{3}$ \\ ${ }^{1}$ Associate Professor at the Economics Department, Faculty of Commerce, Sohag University, Egypt \\ ${ }^{2}$ Visiting scholar at the Claremont Institute for Economic Policy Studies, Claremont Graduate University, USA \\ ${ }^{3}$ The Horton Professor of Economics, Claremont Graduate University and Claremont McKenna College, USA and \\ Director of the Claremont Institute for Economic Policy Studies. \\ Correspondence: Ali A. Massoud, Associate Professor at the Economics Department, Faculty of Commerce, Sohag \\ University, Egypt
}

Received: June 19, 2014

Accepted: July 1, 2014

Available online: August 7, 2014

doi:10.11114/ijsss.v2i4.445

URL: http://dx.doi.org/10.11114/ijsss.v2i4.445

\begin{abstract}
The major purpose of this paper is to analyze the actual exchange rate policies followed by Egypt since the Central Bank of Egypt (CBE) announced its adoption of a floating ER regime in January 2003.

Based on our analytical and empirical approaches to analyzing the actual degree of flexibility of exchange rate policies we concluded the following. First, the de jure "Free Floating" ER Regime that the CBE announced in January, 2003 was not preserved during the period of the study. Second, the changes in the IMF's de facto classifications of Egypt's actual exchange rate policies were broadly accurate. Third, the move from light to heavy exchange market management in 2011 leads to what has been called a one way speculative option. Fourth, too much attention has been paid to the US dollar in setting exchange rate policies. Since the dollar exchange rate sometimes moves substantially against some of these other currencies such as the Euro, it is important that such fluctuations should also be taken into account.
\end{abstract}

Keywords: Exchange Rate Regimes Estimation, Exchange Rate Regimes Classification, Exchange Rate Regimes, Exchange Rate Policies, and Exchange Market Pressure.

\section{Introduction}

In order to make a sound recommendation for a country exchange rate policy, it is valuable to evaluate how well its exchange rate policies have operated in the past. This in turn requires determination of what policies a country actually followed. The latter is a nontrivial question because recent research has shown that the exchange rate regimes that countries actually follow frequently diverge from those officially reported to the IMF.

Where a country is following a narrowly pegged exchange rate, this regime is easy to classify. It is important however to investigate not only the broad type of exchange rate regime that has been adopted but also to analyze how it has been operated with the adjustable peg. The key questions are how frequently and by how much the peg is adjusted and what are the circumstances that lead to such adjustments? More interesting and more difficult to analyze issues arise when countries adopt various forms of flexibility of exchange rate. The easiest of such de facto regimes to analyze in a free float which form a theoretical perspective- regimes that a country never (hardly ever) intervenes in the foreign exchange. In practice the adoption of such genuine free floating regimes is quite rare. The US dollar and euro closely approximate this as have countries such as Canada, Japan, and New Zealand over particular periods, but these are only a small percentage of countries following some types of flexible exchange rate regimes.

Countries sometimes announce that they have adopted a free float when they are in fact using official intervention to manage the exchange rate. This was true of Egypt after 2003. Another example is Korea (see Willett et Al., 2009).

A crawling peg regime, which Egypt announced in January 2001, is easy to classify as a type of regime, but important questions remain about how flexibly it was operated. In most standard classifications, crawling pegs are put more toward the fixed end of the exchange rate spectrum than a managed float. Research has shown however, that some managed floats have operated with less flexibility than some crawling pegs and vice versa (see Willett et al., 2005).For an illustration of this for the exchange rates of several Asian countries before the Asian crisis of 1997-1998.

Thus, with both crawling pegs and managed floats it is important to analyze how they actually operated and how this 
may have varied over time. For example, was there actually more flexibility during Egypt's managed float regime than for its crawling peg and did their relationship vary over different time periods.

The major purpose of this paper is to analyze the actual exchange rate policies followed by Egypt since the Central Bank of Egypt (CBE) announced its adoption of a floating ER regime in January 2003. For these purposes it is not sufficient to determine whether a country has adopted a floating exchange rate. It is also important to analyze how heavily and in what ways the exchange rate is managed. For these purposes we adopt analytic and empirical approaches to review Egypt's exchange rate policies.

The importance of this paper comes from the lack of the study that deals with the issue of the estimation of exchange rate policy in Egypt. Providing an accurate estimation of the exchange rate policy in Egypt helps in providing sound recommendations for the Egyptian authorities in order to deal with the disequilibrium in the foreign exchange market. This enables the Egyptian authorities to adopt the right exchange rate regime that corrects the disequilibrium in foreign exchange market and ends the one direction speculation option on the Egyptian Pound.

Correcting the disequilibrium in the foreign exchange market in Egypt and ending up the one way speculation option helps in correcting other macroeconomic variables in the Egyptian economy. For instance, El-Ramly and Abdel-Haleim (2008) has found that the devaluations of the Egyptian Pound over the period from 1982 to 2004 have an initial contractionary effect on output in Egypt. Massoud (forthcoming) has found an impact of exchange rate movements on domestic prices. CPI and PPI are affected by the movements in exchange rate of the Egyptian Pound.

The remainder of this paper is organized as follows. Section (1) provides a brief summary of the literature that deals with identifying ER regimes. Section (2) presents a historical reading of Egypt's ER regime before the float. Section (3) presents an analytical view for the ER behavior for the Egyptian Pound after the float. Section (4) provides a comparison between our EMP approach and IMF's classification of Egypt's exchange rate regimes. Section (5) presents the findings and policy implications that come out of our study.

\section{Literature Review}

Recent research has shown that countries' actual exchange rate policies often differ from their stated policies. This has given rise to a number of efforts to classify exchange rate regimes on a de facto basis. For a recent review of these measures (see Willett et al., 2011). These include several different types of statistical measures and a new set of classifications from the IMF that is based on its staff judgments in classifying the de facto exchange rate regime for its member countries. For instance, in 1998, the IMF revised its classification of the de jure "Managed Floating" ER regime in Egypt to a de facto "Conventional Fixed Peg" ER regime. The IMF in 2012 revised its own de facto classification of ER regime in Egypt from a "Crawl-Like Arrangement" to a "Stabilized Arrangement".

A heroic effort to classify a large number of exchange rate regimes has been undertaken by Reinhart and Rogoff (2004) while their classification has many desirable features such as including inflation and dual exchange rate regimes, it suffers from looking only at the behavior of the exchange rate and not adjusting for the extent of official intervention. As a consequence they misclassify countries such as Japan and Korea as having free floating regimes over periods in which they had substantial movements in their exchange rates but also massive intervention in the foreign exchange market.

Levy-Yeyati and Sturzenegger (2005) uses cluster analysis of changes in exchange rates regime but their methodology allows them only to differentiate between fixed, crawling peg, and floating rate regimes and does not provide a method of analyzing the degree of official management of flexible regimes. A third approach is presented by Calvo and Reinhart (2002) based on the variances of changes in reserves, exchange rate, and interest rates. The use of the ratios of variances does not allow one to distinguish the extent of management in individual Periods of short duration. The use of interest rates is also problematic as one cannot tell from this statistical data whether an interest rate move by a desire to limit currency depreciation or to diminish the loss of reserves.

For the purpose of this paper we follow the conclusion of recent studies that the approach of looking directly at the ratios of changes in exchange rates is not appropriate. It is important to also take into account the shocks that a country faces. Thus, for example, over a particular period an exchange rate may show little variation because there is heavy official intervention to limit exchange rate fluctuation. But there could also be little interventions and few shocks. Where there are a number of large shocks, a country that intervenes fairly heavily may still have a lower exchange rate variability than a country with a high propensity to intervene in the foreign exchange market, which is the key characteristic of a none flexible management of the exchange rate.

Conceptually the magnitude of shocks in foreign exchange market corresponds to the size of the corresponding shifts in demand and supply schedules for foreign exchange. These shifts correspond to the concept of exchange market pressure (EMP) generated by shocks to foreign exchange market. The foundation of the concept of EMP was introduced by 
Girton, L. and Roper, D., (1977). However, the first use of the concept of exchange market pressure for the statistical measurement of exchange rate flexibility was by Weymark (1995, 1997, and 1998). Her particular methodology suffered from some technical problems, however, see Willett et al (2011) and (2012).

Frankel and Wei (2008 and 2009) and Willett et al (2005) developed another approach also based on the concept of EMP. Their approach investigates the degree to which shifts in demand and supply in the foreign exchange market are allowed to move the exchange rate versus being offset by official intervention. This approach has often been used based on exchange rate behavior with respect to a single major foreign currency. For application for the Japanese yen and Korean won against the dollar see Willett et al (2009), (2012) and (2011). For many countries, however, the exchange rates with respect to more than one foreign currency may be important. To deal with this issue Frankel and Wei (2008 and 2009) developed their approach to include the behavior of multiple foreign exchange rates. Their approach draws on their earlier approach to estimate the de facto weights of a set of foreign currencies where countries are managing their exchange rate against a basket of foreign currencies.

In a freely floating exchange rate the size can be measured by the movement of the exchange rate while under a fixed exchange rate system it would be measured by the size of the amount of official intervention required to maintain the exchange rate constant (in empirical studies this is usually proxied by the change in a country's international reserves). Under a managed float the shock will result in some combination of change in the exchange rate and official intervention. The ratio of the movements in the exchange rate relative to the change in reserves provide a measure of the strength of the propensity of the authorities to intervene in the foreign exchange market and its inverse the degree of exchange rate flexibility.

Ideally one would want to weight the two types of changes by the slope of the excess demand curve in the foreign exchange market. Good estimates of such slopes are not available, however we weight them equally. For discussion of the issues involved in weighting see Willett et al. (2013).

A separate analysis could be undertaken to estimate a Taylor rule type reaction function for a country that includes exchange rate in the reaction function. A complete analysis of a country's exchange rate cum Monetary regime would include estimates of the extent to which the domestic monetary effects of exchange market intervention are sterilized or not.

For discussion of this and farther analysis of the other statistical measures (see Willett et al., 2011). In addition to these statistical measures, there is also now available at the IMF a set of de facto classifications based on the judgment of IMF staff about the exchange rate policies actually followed. For many purposes these classifications are extremely useful but they are weak in terms of characterizing the extent of management of the managed floats. We do however compare our statistical measures with the de facto classification of the IMF. Again see the survey by Willett et al (2011).

There are two studies that examined the de facto ER regime in Egypt. The first study is Selim (2010). The study investigated if there was a significant change in the exchange rate behavior with the announcement of the float of the Egyptian Pound on January, 2003. It used LYS methodology in order to classify Egypt's exchange rate after the float. The study used the Chow test for structural break. It concluded that according to the Chow test's results, there was no significant change associated in the exchange behavior with the announcement of the float. The author concluded that she was not able to classify the Egyptian exchange regime by using LYS methodology.

The second study is Kamar and Bakardzhieva (2005). This study used a single-equation approach to cointegration. It concluded that the Egyptian authorities have always managed the exchange regime, whether under the label of "adjustable peg", "crawling peg" or the de facto management of its de jure free float. This conclusion leaves open, however, the important question of how heavily the exchange rate is managed.

\section{Reading the History of ER Regime in Egypt before the announcement of the float: an Analytical Approach}

Before we analyze the de facto ER regime in Egypt after the floating of the Egyptian Pound in January 2003, we believe that it is important to read the history of how Egypt ER regime was operated in the previous periods. We are not doing so in a purely narrative way, rather we connect the analysis of the ER regime to two dimensions. The first dimension is the movements in ER of the Egyptian Pound. The second dimension is the movements of the total foreign reserves at the Central Bank of Egypt. In this section, we examine the ER regimes that Egypt followed before the de jure floating ER regime that took place in January 2003. We can distinguish between three ER regimes that Egypt followed during this period. These ER regimes are: fixed adjustable peg, managed floating, and crawling peg. The rest of this section sheds the light on how ER regime in Egypt had been operated before the float.

\subsection{The Fixed but Adjustable Peg ER Regime}

Starting from the sixties till 1990, Egypt had put a fixed but adjustable peg in practice. The Egyptian authority had kept the ER of the Egyptian Pound fixed to the USD. The CBE had adjusted the ER of the Egyptian pound from 1.1 LE per 
$1 \$$ to 2 LE per $1 \$$ in July 1990 . Chart (1) captures the jump of the ER for the Egyptian pound. The question here is: What is the impact of this devaluation on reserves? Chart (2) shows that reserves had grown after the devaluation of the Egyptian Pound. Reserves had increased from 1.6 BL \$ in July 1990 to 2.7 BL \$ in December 1990 and jumped in January 1991 to 3.2BL\$. This may indicate that the CBE allowed the ER of the Egyptian Pound to move and did not intervene to prevent the deterioration of its value against the USD. This may be true. However, we rather argue that the CBE might intervened against the wind to keep the ER of the Egyptian Pound at 2 LE per $1 \$$ but if failed to do so. We build our argument on two points: the first one is the decline in reserves over the last two months in 1990. Reserves declined from 3.9 BL\$ in October 1990 to 2.7 BL\$ in December 1990. The second is that, if the CBE could defend its fixed adjustable peg, it would not change it shortly at the beginning of 1991.

\subsection{The Managed Floating ER Regime}

In February 1991 as a part of the economic reform program, the Egyptian authority changed its ER policy from the adoption of a fixed but adjustable peg ER regime to a managed floating ER regime. As a result of the new regime, the ER of the Egyptian Pounds devalued from 2LE per 1\$ to 3.4\$, on average between February 1991 and December 2000. As chart (1) shows, the ER of the Egyptian Pound was moving up slowly against the USD. Regarding reserves, during the period from January 1991 to December 2001, we can distinguish between two sub-periods. The first period is from January 1991 to September 1997. Over this period, reserves increased steadily from 3.1BL\$ in January 1991 to reach its peak of 19.1 BL\$ in September 1997, as chart (2) shows. This may have happened because of the foreign debt relief for Egypt as a result of its reaction to the first "Gulf War" in 1991.The CBE had kept the ER for the Egyptian Pound to what extent stable against the USD. The second period from October 1997 to December 2000. As chart (1) shows, the CBE had kept the ER for the Egyptian Pound fixed against the USD at 3.388 LE per $1 \$$ between October 1997 and January 1999. But how did the CBE had keep the ER of the Egyptian Pound fixed during this period? Chart (2) provides an answer. As chart (2) shows, the CBE had lost about 5\% of its reserves. Reserves declined to be about 18BL\$. As a result of losing reserves, the CBE had depreciated the ER of the Egyptian Pound through 1998 and 1999. However, it continued to lose reserves to the point that the reserves stock was only 13.1BL\$ in December2000. It is worth mentioning that during this period, Egypt was exposed to three major shocks: (1) the terrorist act in Luxor in 1997 and its implications on the tourism sector, which is considered to be a main source of foreign currencies in Egypt. (2) the Asian Crisis that took place in 1997 and 1998 and caused huge capital outflows from Egypt. (3) the second" INTIFADAH" for the Palestinian people which took place in 2000 and its negative implications on the Egyptian economy, especially on tourism and foreign investments. In 1998, the IMF revised its classification of the de jure "Managed Floating" ER regime in Egypt to a de facto "Conventional Fixed Peg" ER regime rather than the official classification of a managed float regime. Table (1) in the appendix shows the history of the IMF's de facto classifications of Egypt's exchange rate regime.

\subsection{The Crawling Peg ER Regime}

In January 2001, the CBE announced the adoption of a de jure" Crawling Peg ER Regime". Over the period from January 2001 to December 2002, the ER of the Egyptian Pound was devalued three times. The first time was when the CBE adopted the new ER regime. At that time the ER for the Egyptian Pound was set at 3.85 LE per 1\$. The second time was on September 2001, as a result of the 9/11 terrorist act against the USA and its implications on the Egyptian economy. The CBE devalued the Egyptian Pound to 4.14 LE per 1\$. The third time was in January 2002. As the effects of the 9/11 attack continued, the losses in the tourism sector in Egypt continued, the CBE forced to devalue the Egyptian Pound one more time and it set the ER at 4.5 LE per 1\$. The CBE kept this rate till its announcement of adopting floating ER regime in January 2003. Chart (1) and chart (5) capture these developments in the ER of the Egyptian Pound. During this period of adopting a de jure "Crawling Peg ER Regime", reserves fluctuated between 14.1BL\$ (in July 2001) and 12.5 BL\$ (in February 2002), as Chart (2) and chart (6) show.

\subsection{Conclusion}

From our analytical review of the history of the ER regimes in Egypt, we reach the following conclusions:

1- When Egypt was exposed to external or internal shocks, the Egyptian authorities, in most of the cases, tried to absorb these shocks by leaning against the wind, then once it to lost reserves to a critical point, the CBE allowed the ER of the Egyptian Pounds to depreciate and an announcement adopting of a new ER regime was made.

2- External shocks and their implications on the Egyptian economy were, in almost all the cases, the major reason for the CBE to adopt new ER regime.

3- The ER of the Egyptian Pound during this period, regardless the de jure ER regime or the de facto ER that CBE put in practice, was pegged to the USD in tighter or looser ways. 


\section{The de facto vs. the de jure Egyptian ER Regime after the Float}

In January 2003, the CBE announced the new" Free Floating ER Regime" to be followed in Egypt. Since this time, there have been doubts that this de jure "Free Floating" was really being followed by the CBE. This doubt spread not only among market participants, but also among local economists and those at the IMF. After only a year of the new de jure ER regime, the IMF revised its classification of Egypt's ER regime as follows. In 2004, 2005, and 2006, the IMF classified Egypt's ER regime to a de facto "Managed Floating With no predetermined path for ER" combined with a policy framework defined as following a "Monetary Aggregate Target". In 2008, the IMF changed its classification of Egypt's ER regime to a de facto "other Conventional Fixed Peg Arrangement" with ER as a nominal anchor. In 2009, the IMF again reclassified Egypt's ER regime as a de facto "Managed Floating with no Predetermined Path for ER". In 2011, the IMF reclassified Egypt's ER regime as a de facto "Craw-Like Arrangement". Few months later, in 2012, the IMF reclassified Egypt's ER regime as a de facto "Stabilized Arrangement". In 2013, the IMF reclassified Egypt's ER regime as a de facto "Craw-Like Arrangement" with the ER used as a nominal anchor.

It is worth mentioning that in estimating Egypt's exchange rate regime after the float using EMP approach, we faced major difficulties. These difficulties were the common three major difficulties in applying the EMP approach to evaluating the degree of flexibility or management of a country's exchange rate policy. One is to obtain data on the country's exchange market intervention. Few countries make this information public. Thus, researchers had to use reported changes in reserves as a crude proxy. At least three problems make this an imperfect proxy. First, some increases in reserves such as some that accompany foreign aid do not go through the market. Secondly, interest earnings on reserves lead to increases in the stock of reserves without intervention. Third, changes in exchange rates may lead to valuation changes. On average these considerations lead increases in reserves to overstate amounts of intervention and declines in reserves to understate intervention. Thus, for example the modest increases in Egypt's reserves in 2008 through 2010 should not be taken as indication that there was any substantial intervention to push up the currency.

A second problem is that a country has exchange rates against many currencies while many studies have used just the exchange rate against a major currency such as the dollar. Fluctuations in the value of the dollar against third currency can influence the overall degree of flexibility of a country's currency. Frankel and Wei (2008) and (2009) have developed an approach to estimating the implicit weights in a country's policies toward a basket of currencies. This approach was extended from estimating the weights in basket pegs to cases of greater exchange rate flexibility. However, their technique has been less successful in in this content. We applied their approach to Egypt during the floating rate period but results often did not make sense.

The third problem in that the EMP index of flexibility is clearly defined only in the cases where the central bank is intervening against the wind, i.e. accumulating reserves to hold down the rate of appreciation or using reserves to limit depreciations. Sometimes, however, previous studies have found reserve increases while currencies are depreciating or reserve losses when currencies are appreciating. Egypt has been no exception. Such "wrong sign" episodes are likely frequently due to the imperfect nature of reserve changes as a proxy for actual intervention. Where this isn't the case it would will that the country was actively intervening to increase rather than reduce exchange rate movements. Such actions could be interpreted either as super flexibility or as super management.

In the previous section, we concluded that the Egyptian authorities had been trying to limit the fluctuations of the ER of the Egyptian Pound against the dollar as much as it can. To investigate to what extent this occurred, we examined the behavior of the ER of the Egyptian Pound with respect to the USD and two other main currencies, the Euro and the British Pound. Chart (3) shows that the ER of the Egyptian Pound against the USD was fairly stable compared with the ER of the Egyptian Pound against both the Euro and the British Pound through the period from January 2003 to November 2012. This finding indicates that the CBE had used the ER of the Egyptian Pound against the USD as an implicit anchor for its monetary policy. As chart (4) shows, the ER of the USD went through periods of depreciation and appreciation between January 2003 and December 2012.

By comparing the ER of the Egyptian Pound against the Euro and the British Pound during the same period, as chart (3) shows, we see that the ER of the Egyptian Pound against these two currencies had followed almost the same behavior of the ER of the USD against these two currencies. This finding supports our argument of that the CBE was using the ER of the Egyptian Pound against the dollar as an anchor for monetary policy in Egypt and allowing it to move more flexibly against the euro and the British Pound. Another point that supports our argument is that since the CBE adopted the new system in the exchange market with the auctions for USDs in December 2012, the ER of the Egyptian Pounds has fluctuated against the USD dollar and against both the Euro and the British Pound. These movements were captured in chart (3).

In the remaining part of this section, we discuss four main shocks that faced the Egyptian economy during the period of our study as follows. 


\subsection{Floating the Pound in January 2003}

In January 2003, the CBE announced the adoption of the" Free Floating ER Regime". As shown in Charts (1 and 7), the Egyptian Pounds lost around 20\% of its value against the USD during the month of the adoption of the new regime. The ER of the Egyptian Pound increased from 4.5 LE per 1 \$ to be 5.4 LE per $1 \$$. This depreciation continued untill December 2004, when the ER for the Egyptian Pound reached 6.3 LE per 1\$. During this period, reserves were fluctuating with an increasing trend. They increased from 12.9 BL\$ in December 2002 to 14.3 BL\$ in December 2004. As charts (3 and 4) show, the CBE during this period was intervening to keep the ER of the Egyptian Pound against the USD as quite stable.

\subsection{Inflation Targeting in January 2005}

In January 2005, the CBE announced its intention to adopt inflation targeting as a nominal anchor for the monetary policy over the medium term. This step affected the ER of the Egyptian Pound instantly. The Egyptian Pound appreciated against the US, moving from 6.1 LE per $1 \$$ to be $5.8 \mathrm{LE}$ per $1 \$$. As charts (1 and 9) show, the ER of the Egyptian Pound appreciated modestly then fluctuated within a narrow range against the USD. Once again this was not the case for the ER of the Egyptian Pound against the Euro and the British Pound as chart (3) shows. Chart (10) shows that reserves steadily increased from 15.4 BL\$ in January 2005 to $21.3 \mathrm{LB} \$$ in June 2006. This trend in reserves continued on untill December 2010 when the reserves stock reached a record of 33.6 BL\$.

\section{$4.325^{\text {th }}$. Of January Revolution in 2011}

In $25^{\text {th }}$ of January 2011, what is called the $25^{\text {th }}$ of January revolution erupted. As a result, Egypt has been in political and social instability. There have been great impacts of this event on the Egyptian economy. What happened in the exchange market was not far from what was going on in the political scene. It might be expected that the ER of the Egyptian Pound would depreciate substantially. Surprisingly, as shown in chart (11), this was not the case. The ER of the Egyptian Pound against the USD was fairly stable, only depreciating from 5.8 LE per $1 \$$ in January 2011 to be 6.1 LE per $1 \$$ in November 2012. Two main things explain this behavior. First, the huge amount of the decline that happened in reserves during this period. As chart (2) shows, by the end of year 2012, reserves had dramatically declined to a very low level indicating that the authorities had been intervening heavily to prop up the currency. Reserves declined to 11.6 BL \$ from 32.6BL\$ in January 2011. Secondly, as Chart (3) shows, during this period while the ER of the Egyptian Pound was fairly stable against the dollar, it was fluctuating substantially against both the British Pound and the Euro. Thus, there is a strong evidence that the CBE had been intervening extensively to keep the ER of the Egyptian Pound stable against the USD.

\subsection{The Introduction of Auctions of USDs in December 2012}

In order to stop the huge losses of reserves and to take a step farther to put the floating ER regime in practice, the CBE announced the adoption of a new system of putting the USD on auction.

The quick result of the new regime was the depreciation of the Egyptian Pound against the USD, the Euro, and the British Pound. Charts (3 and 13) show that.

\section{EMP Flexibility Assessment of Egypt's Exchange Rate Regime and the IMF Classifications}

The following table shows the IMF de facto classifications of exchange rate regime in Egypt during the period from 2003 to 2013. In columns (1 and 2), we calculated the change in exchange rate of the Egyptian Pound against the US dollar and the changes in the ratio of international reserves to monetary base for each individual year from 2003 to 2013. From this table we can conclude that the exchange rate of the Egyptian pound was managed with various degree of flexibility against the US dollar, but has never been allowed to freely float.

As table (1) shows, during Egypt's floating rate period there have been a number of such "wrong signs" but they have generally been cases where were small. Thus, we are inclined toward interpreting most of these years such as 2003 and 2004 as ones with a high degree of flexibility. For further discussion of this issue see Willett et al. (2011). 
Table 1. Changes in the exchange rate \& reserves and IMF de facto classifications of ER

\begin{tabular}{|c|c|c|c|c|}
\hline Year & $\begin{array}{l}\text { Annual changes } \\
\text { in } \operatorname{ER}(\%)\end{array}$ & $\begin{array}{l}\text { Annual changes in } \\
\text { reserves }(\%)\end{array}$ & IMF Classifications & $\begin{array}{l}\text { Change in Reserves/MB }(\%) \\
\text { (monthly average for each year) }\end{array}$ \\
\hline 2003 & 34.86597 & 4.997293 & $\begin{array}{l}\text { Managed floating with no } \\
\text { pre-determined path for the exchange } \\
\text { rate }\end{array}$ & 0.0444 \\
\hline 2004 & 0.82348 & 8.507654 & $\begin{array}{l}\text { Managed floating with no } \\
\text { pre-determined path for the exchange } \\
\text { rate }\end{array}$ & 0.050506 \\
\hline 2005 & -2.292 & 33.39 & Managed floating & 0.333213 \\
\hline 2006 & -0.32999 & 17.05889 & $\begin{array}{l}\text { Other conventional fixed peg } \\
\text { arrangements }\end{array}$ & 0.138936 \\
\hline 2007 & -3.1086 & 23.13235 & Managed floating & 0.156657 \\
\hline 2008 & 0 & 4.850766 & $\begin{array}{l}\text { Managed floating with no } \\
\text { pre-determined path for the exchange } \\
\text { rate }\end{array}$ & 0.047475 \\
\hline 2009 & -0.83593 & 2.28691 & Other Managed Arrangement & 0.003486 \\
\hline 2010 & 6.352521 & 4.049083 & Other Managed Arrangement & 0.036144 \\
\hline 2011 & 3.563728 & -54.0279 & Crawl-like arrangement & -0.57313 \\
\hline 2012 & 2.072195 & -11.3716 & Stabilized arrangement & -0.10283 \\
\hline 2013 & 5.392936 & 32.55826 & Crawl-like arrangement & 0.137716 \\
\hline
\end{tabular}

Source: Authors calculation from the IFS data base.

To estimate the degree of the flexibility of the exchange rate regime in Egypt, we used the exchange market pressure (EMP) methodology introduced by Frankel and Wei (2008 and 2009). This approach investigates the degree to which shifts in demand and supply in the foreign exchange market are allowed to move the exchange rate versus being offset by official intervention. This approach has often been used based on exchanged rate behavior with respect to a single major foreign currency. For application for the Japanese yen and Korean won against the dollar see Willett et al (2009) and (2011). For many countries, however, the exchange rates with respect to more than one foreign currency may be important. To deal with this issue Frankel and Wei (2008) and (2009) developed a methodology that includes the behavior of multiple foreign exchange rates.

Following Frankel and Wei (2008 and 2009), we define the EMP as the percentage change in the value of the currency plus the change in reserves as a fraction of the monetary base. The Special Drawing Right (SDR) is used as a numeraire following Frankel and Wei (2004, 2008, and 2009). To avoid non-stationarity that is likely to occur in time series, the variables are used in terms of changes rather than levels.

Following Frankel and Wei, we used the following equation in order to estimate the degree of flexibility of the ER in Egypt after the float.

$$
\Delta \log E G Y P_{t}=C+\sum w(j) \Delta \log X(j)_{t}+\delta\left\{\Delta \operatorname{emp}_{t}\right\}+\mu_{t}
$$

Where:

$\Delta \log \boldsymbol{E} G Y \boldsymbol{P}_{t}$ is the change of the $\log$ value of the Egyptian Pound ER ( per SDR) in period t.

$\Delta \log X(j)_{t}$ is the change of the log value of the currencies $\left(X_{1}, X_{2}, \ldots\right.$, and $\left.X_{n}\right) E R($ per SDR) in period t.

$\boldsymbol{w}(j)$ is the coefficient that represents the de facto weights of the used currencies and it will be $\mathrm{w}_{1}, \mathrm{w}_{2}, \ldots$, and $\mathrm{w}_{\mathrm{n}}$

$$
\Delta \mathrm{emp}_{t}=\Delta \log E G Y P_{t}+\Delta \operatorname{Res}_{t} / M B_{t}
$$

Where:

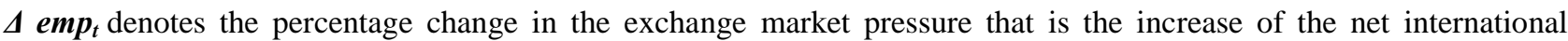
demand for the Egyptian Pound, which may show up in either in the price of the Egyptian Pound or the change in the quantity of international reserves depending on the policies of the CBE (floating vs. fixed).

$\boldsymbol{\delta}$ denotes the coefficient that captures the de facto degree of exchange rate flexibility. It takes values between 0 and 1 . If 
$\delta=0$ this means the ER of the Egyptian Pound is fixed, while if $\delta=1$ this mean that ER of the Egyptian Pound is freely floating. Any number in between represents the degree of flexibility of the ER for the Egyptian Pound. USD, Euro, and BP were picked as the weighted basket, as they are the three major currencies affecting Egypt's international transactions. Thus, we can rewrite equation (1) to be the following.

$$
\Delta \log E G Y P_{t}=C+w_{1} \Delta \log U S D_{t}+w_{2} \Delta \log E U R O_{t}+w_{3} \Delta \log B P_{t}+\delta\left\{\Delta e m p_{t}\right\}+\mu_{t}
$$

We dropped using the Saudi Real and Kuwaiti Dinar because they are pegged to the dollar. Also, we dropped using the UAE Dirham because it is pegged to a basket of currencies that are dominated by the USD, Euro, and BP.

While this approach was originally developed using the home exchange rate against only one major foreign currency, a broader approach has been introduced by Frankel and Wei (2008 and 2009).

The following table shows the summary of the estimation results:

Table 2. The Estimation Results

\begin{tabular}{lllll}
\hline Coefficients & Period & Period & $\begin{array}{l}\text { Period } \\
(1)\end{array}$ & $\begin{array}{l}\text { Period } \\
(2)\end{array}$ \\
\hline USD & 0.0200 & 0.0223 & 0.015 & 0.171 \\
& $(1.382)$ & $(1.589)$ & $(1.120)$ & $(4.800)$ \\
EURO & 0.0005 & 0.0009 & 0.003 & -0.006 \\
& $(0.181)$ & $(0.370)$ & $(1.270)$ & $(-0.925)$ \\
BP & 0.00002 & 0.00002 & -0.0002 & -0.0001 \\
& $(0.647)$ & $(0.639)$ & $(-1.342)$ & $(-0.635)$ \\
$\boldsymbol{\Delta}$ emp & 0.876 & 0.871 & 0.975 & 0.031 \\
& $(21.087)$ & $(20.710)$ & $(27.139)$ & $(0.293)$ \\
Constant & -0.00008 & -0.00006 & -0.001 & 0.0012 \\
& $(-0.302)$ & $(-0.232)$ & $(-5.371)$ & $(2.567)$ \\
$\mathrm{R}^{2}$ & 0.885 & 0.896 & 0.957 & 0.939 \\
F & 234 & 244 & 370 & 70 \\
DW & 0.995 & 0.740 & 0.893 & 1.393 \\
Obs. & 127 & 119 & 72 & 23 \\
\hline
\end{tabular}

As table (2) shows, we estimated the index of flexibility ( $\delta$ ) for Egypt's ER regime using four periods of time as follows.

\subsection{Period (1): from January 2003 to August 2013}

This period covers the time frame from the announcement of the float till the last month for which data is available at the IFS. As regression (1) shows, the flexibility index is 0.867 . This findings mean two things. First, it means that Egypt's exchange rate regime was not free float as officially stated. Second, it rules out the argument that the CBE uses the ER of USD as a nominal anchor. The latter goes along with the announcement of the CBE in January 2005 regarding using inflation targeting as an explicit anchor for monetary policy. Another interesting finding can be seen from regressions (1) regarding the weights of various international currencies. As regressions (1) shows, the coefficients for all international currencies were very small and the coefficient for the USD was the largest among these currencies. This means that the CBE during this period was not pegging the pound against a basket of currencies or to the USD. Rather, it was keeping an eye on the ER of the Egyptian Pound in relationship with the dollar. However, this relationship was not strong enough to be classified as pegging the Egyptian Pound to the USD. Finally, $\mathrm{R}^{2}$ and F-statistics in regression (1) suggest that the model fit the data well.

\subsection{Period (2): from January 2003 to November 2012}

This period covers the time frame from the announcement of the float until the adoption of the new system according to which the CBE allows auctions on the USDs. As regressions (2) shows, there was not a substantial difference when we dropped out the observations after the auctions' system was introduced by the CBE in December 2012. This may be because the number of the omitted observations was small, just 9 observations. This makes estimating Egypt's ER 
regime in the future an important issue in deciding whether adopting the auctions' system affecting the flexibility of Egypt's ER regime or not?

\subsection{Period (3): from January 2005 to December 2010}

This period covers the time frame from the announcement of the intention of the CBE to adopt inflation targeting as an anchor for monetary policy in Egypt until the $25^{\text {th }}$ of January revolution. As regressions (3) shows, during this period, flexibility index increased in a substantial amount. It increased from 0.87 to 0.97 which is consistent with the announcement of the CBE of its intention of using inflation targeting as a nominal anchor for monetary policy over the medium term. Also, $\mathrm{R}^{2}$ increased from 0.88 to 0.96 which means the model even fits the data better.

\subsection{Period (4): from January 2011 to November 2012}

This period covers the time frame from the $25^{\text {th }}$ of January revolution till the adoption of the auctions system. This period had witnessed a huge lost in reserves which may indicate that the CBE was leaning against the winds strongly to prevent the depreciation of the Egyptian Pound. The results of the estimations, as shown in regressions (4) support this view. In this period, the flexibility index declined dramatically from 0.87 to 0.03 which means that the ER regime that the $\mathrm{CBE}$ followed during this period was not allowing the shock in the ER market to show up in the ER of the Egyptian Pound. Rather, it allowed it to show up in the level of reserves. The increase of the USD coefficient form 0.02 to 0.17 suggests that the CBE was taking in consideration the ER of the Pound against the dollar during this period much more than it has been before.

\section{Findings and Policy Recommendations}

Egypt has had considerable variability in its exchange rate policies over years. During the more recent years of Egypt's official float, its policies have actually varied quite widely. In its early days, exchange rate policy was indeed quite flexible, but as has often been the case over time management frequently became heavier.

Building on our analysis, we summarize our findings as follows:

1- Since 1990's, when Egypt was exposed to external or internal shocks, the Egyptian authorities, in most of the cases, tried to absorb these shocks by leaning against the wind, then once it to lost reserves to a critical point, the CBE allowed the ER of the Egyptian Pounds to depreciate and an announcement of adopting of a new ER regime was made.

2- External shocks and their implications on the Egyptian economy were, in almost all the cases, the major reason for the CBE to adopt new ER regimes.

3- The ER of the Egyptian Pound before announcing the float, regardless the de jure ER regime or the de facto ER that CBE put in practice, was pegged to the USD in tighter or looser ways.

4- The de jure "Free Floating" ER Regime that the CBE announced in January, 2003 was not preserved during the period of the study. The de facto exchange rate of the Egyptian Pound was a managed exchange rate regime with various degree of flexibility against the US dollar, but has never been allowed to freely float. Egypt is not the only country that has claimed to have adopted a free float while continuing to intervene heavily at times to limit its fluctuations. This gives another illustration of the importance of carefully investigating the exchange rate regimes actually being followed by countries rather than relying exclusively on what governments state their policy to be. This finding goes along with what Kamar and Bakardzhieva (2005) has concluded. The study has concluded that the Egyptian authorities have always managed the exchange regime, whether under the label of "adjustable per", "Crawling peg" or the de facto management of its de jure free float.

5- The move from light to heavy exchange market management in 2011 is a source of concern. Where exchange rates are heavily managed in the face of continuing exchange market pressures, the government begins to generate perverse expectations similar to these that generated such great speculative problems under adjustably pegged exchange rate regimes. Such prolonged heavy intervention sets up what has been called a one way speculative option. Participants don't know if these will be a major change in the exchange rate over the near but they do know the direction which any major change would be. These prolonged heavy intervention rather offsetting speculative pressures can generate even greater ones. This appears to have been the case in Egypt.

6- Based on our EMP approach to analyzing the actual degree of flexibility of exchange rate policies we found that the changes in the IMF's de facto classifications of Egypt's actual exchange rate policies were broadly accurate.

7- This study uses the official exchange rate for the Egyptian Pound against the dollar. However, because of the instability in the foreign exchange market in Egypt and the shortage of foreign currencies in this market, black market existed during the study period. Since we do not have access for the data on the exchange rate for the 
Egyptian Pound in the black market, we did not consider it in our study. Thus, we recommend further research to look at the exchange rate of the Egyptian Pound in the black market.

There are some important policy recommendations drown out of this paper. We advise the Egyptian authorities to do the following:

1- Over the study's period, there were more than one exchange rate for the Egyptian Pound. These rates are the official rate, the unofficial rate at foreign exchange companies, and the unofficial rate in the black market. The Egyptian authorities must take all measures that ensure a unified exchange rate for the pound. We believe that only lightly managed floating is the most reasonable means to achieve a unified exchange rate for the pound.

2- We also have concern that too much attention has been paid to the US dollar in setting exchange rate policies. Clearly, the exchange rate against the dollar is the most important exchange rate, but several other currencies are also important for Egypt's international transactions. Since the dollar exchange rate sometimes moves substantially against some of these other currencies such as the Euro, it is important that such fluctuations should also be taken into account.

Thus, if the Egyptian authorities have to intervene in the foreign exchange market to stabilize the exchange rate for the Egyptian Pound, it should not only intervene against the dollar. Rather, they should consider other major currencies that are important in the international transactions for Egypt.

3. Exchange rate policy should more consistently follow a lightly managed float. There are times when it is appropriate for the central bank to intervene in the foreign exchange market to smooth exchange rate fluctuations and help maintain an orderly foreign exchange market. As noted above, however, continued high levels of intervention can lead to overvalued exchange rates that result in destabilizing rather than stabilizing the market. Thus, excessively heavy management of the exchange rate can prove to be highly disruptive, as recent events have shown.

\section{References}

Cavoli, T., \& R., Rajan (2010). A Note on Exchange Rate Regimes in Asia: Are They Really What They Claim to Be? Economics Bulletin, 4 (4), 2864-2876

Calvo, G., \& C., Reinhart (2002). Fear of Floating. Quarterly Journal of Economics CXVII, 379-409. http://dx.doi.org/10.1162/003355302753650274

El-Ramly, H., \& S. Abdel-Haleim (2008). The Effect of Devaluation on Output in the Egyptian Economy: A Vector Autoregression Analysis. International Research Journal of Finance and Economics.

Frankel, J. (2009). New Estimation of China's Exchange Rate Regime. Pacific Economic Review, 14(3). http://dx.doi.org/10.1111/j.1468-0106.2009.00454.x

Frankel, J., \& S., Wei (2008). Estimating of De Facto Exchange Rate Regimes: Synthesis of the Techniques for Inferring Flexibility and Basket Weights. NBER Working Paper Series, WB14016.

Girton, L., \& Roper, D. (1977). A Monetary Model of Exchange Market Pressure Applied to the Postwar Canadian Experience. American Economic Review September, 537-548.

Kamar, B., \& D., Bakardzhieva (2005). Economic Trilemma and Exchange Rate Management in Egypt. Review of The Middle East Economics and Finance, 3(2). http://dx.doi.org/10.1080/14753680500166441

Levy-Yeyati, E., \& F., Sturzenegger (2005). Classifying Exchange Rate Regimes: Deeds vs. Words. European Economic Review, 49, 1603-1635. http://dx.doi.org/10.1080/14753680500166441

Seliem, H. (2010). Has Egypt's Monetary Policy Changed After the Float? Econ Papers No.543, Economic Research Forum.

Reinhart, C., \& K., Rogoff (2004). The Modern History of Exchange Rate Arrangements: A Reinterpretation. Quarterly Journal of Economics, 119, 1-48. http://dx.doi.org/10.1162/003355304772839515

Weymark, D. (1995). Estimating exchange market pressure and the degree of exchange market pressure for Canada. Journal of International Economics, 39, 273-295. http://dx.doi.org/10.1016/0022-1996(95)01389-4

Weymark, D. (1997). Measuring the Degree of Exchange Rate Market Intervention in a Small Open Economy. Journal of International Money and Finance, 16, 55-79. http://dx.doi.org/10.1016/S0261-5606(96)00048-4

Weymark, D. (1998). A General Approach to Measuring Exchange Market Pressure. Oxford Economic Papers, 50, 106-121. http://dx.doi.org/10.1093/oxfordjournals.oep.a028632

Willett, T., et al. (2012). Measuring Exchange Rate Flexibility: A Two-Parameter Market Pressure Approach. Global Journal of Economics, 2012. 1 
Willett, T., Chiu, M. P., Dechsakulthorn, S., Ghosh, R., Kibesse, B., Kim, K., Kim, Y, \& Ouyang, A. (2011). Classifying international aspects of currency regimes. Journal of Financial Economic Policy 3, $288-303$. http://dx.doi.org/10.1108/17576381111182882

Willett, T., \& Kim, Y. (2006). Korea's Post Crisis Exchange Rate Policy. Korea's Economy 2006, 5-15.

Willett, T., Nitithanprapas, E., Nitithanprapas, I., \& Rongala, S. (2005). The Asian Crises Reexamined. Asian Economic Papers, 3, 32-87. http://dx.doi.org/10.1162/1535351054825184

Willett, T. (2003). Fear of Floating Needn't Imply Fixed Rates: Feasible Options for Intermediate Exchange Rate Regimes. Open Economies Review, 14, 71-91. http://dx.doi.org/10.1023/A:1021251303089

\section{Appendix (1)}

Table (1) IMF classification of Egypt ER regime

\begin{tabular}{|c|c|}
\hline Year & Egypt ER regimes' classification \\
\hline 2013 & Crawl-like arrangement \\
\hline 2012 & Stabilized arrangement \\
\hline 2011 & Crawl-like arrangement \\
\hline 2010 & Other Managed Arrangement \\
\hline 2009 & Other Managed Arrangement \\
\hline 2008 & Managed floating with no pre-determined path for the exchange rate \\
\hline 2007 & Managed floating \\
\hline 2006 & Other conventional fixed peg arrangements \\
\hline 2005 & Managed floating \\
\hline 2004 & Managed floating with no pre-determined path for the exchange rate \\
\hline 2003 & Managed floating with no pre-determined path for the exchange rate \\
\hline 2002 & "Pre announced horizontal band that is narrower than or equal to $+/-2 \% "$ \\
\hline $2000-2001$ & "Pre announced horizontal band that is narrower than or equal to $+/-2 \%$ " \\
\hline 1999 & Pre announced horizontal band that is narrower than or equal to $+/-2 \%$ \\
\hline 1991-1998 & $\begin{array}{l}\text { Conventional Fixed Peg } \\
\text { "Pre announced horizontal band that is narrower than or equal to }+/-2 \% "\end{array}$ \\
\hline $1970-1990$ & De facto peg \\
\hline
\end{tabular}

Notice: data from 1970 to 2002 was taken from: Carmen M. Reinhart and Kenneth S. Rogoff (2014). "This Time is Different: Eight Centuries of Financial Folly." Princeton University Press.

Chart 1. Annual ER per \$ from 1990:2012

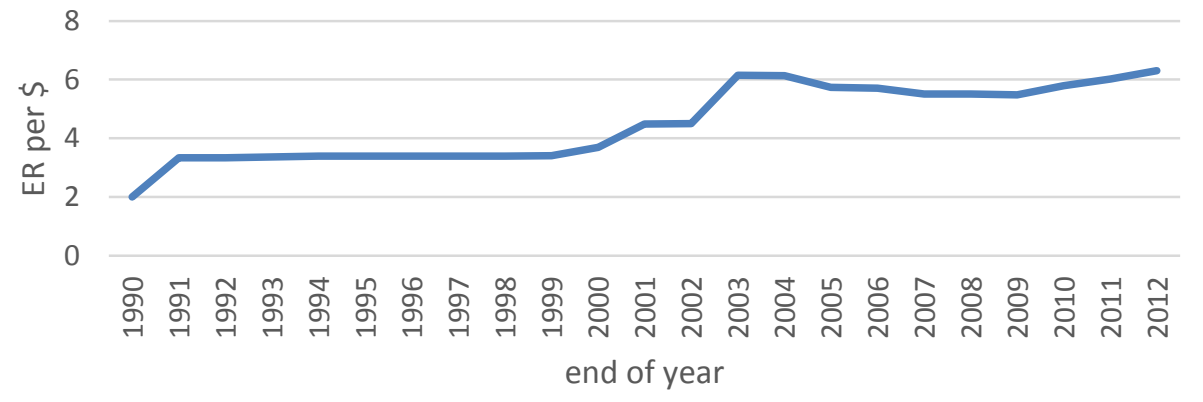


Chart 2. Total Res. from 1990:2012 in BL\$
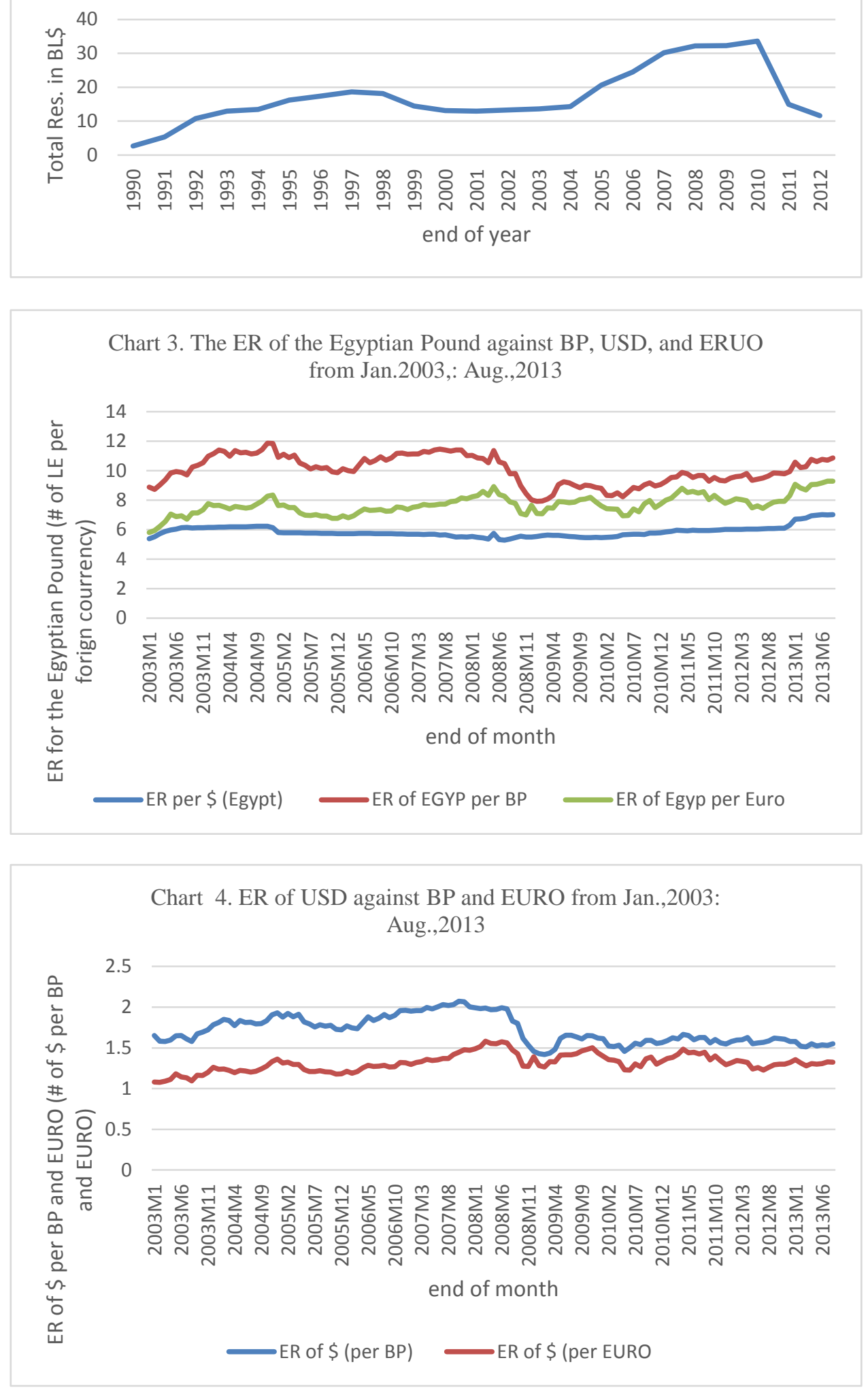
Chart 5. ER per \$ from Jan.,2000: Dec.,2002

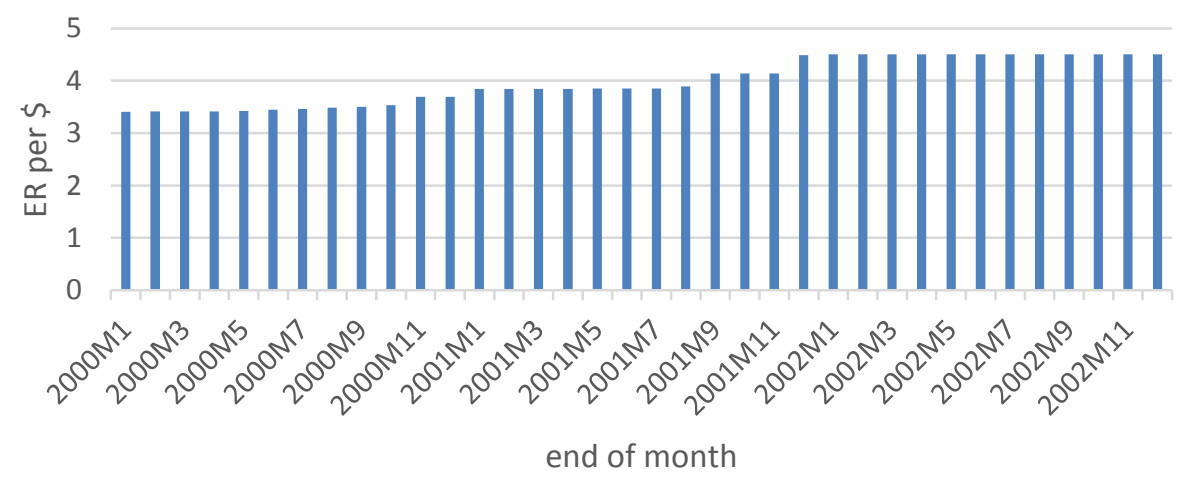

Chart 6. Total Res. from Jan.,2000:Dec., 2002 in BL\$

14.5
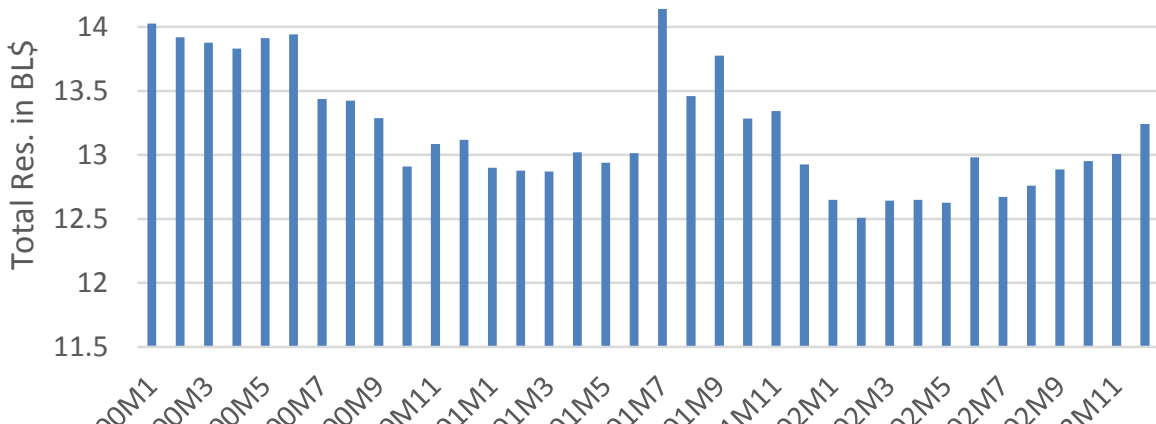

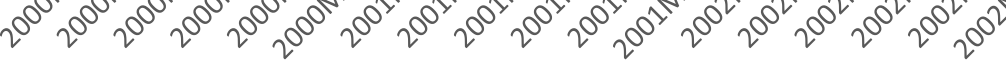

end of month

Chart 7. ER per \$ from June,2002: Dec.,2004

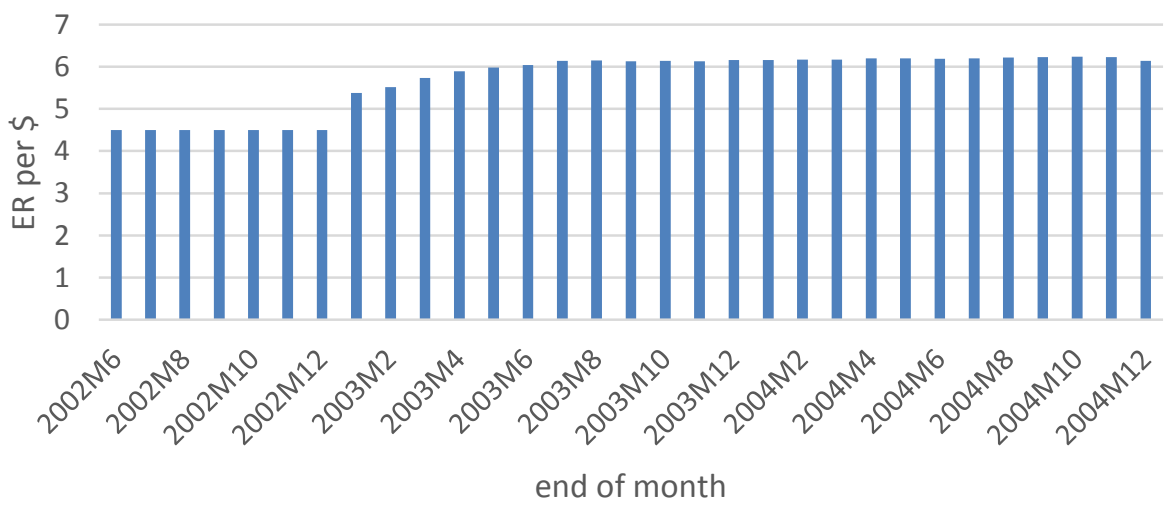


Chart 8.Totl Res. from June,2002:Dec.,2004 in BL\$
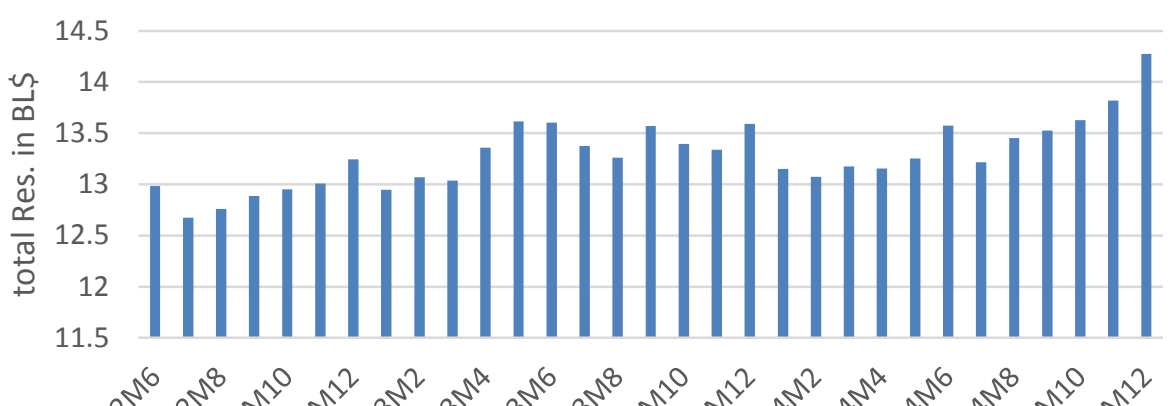

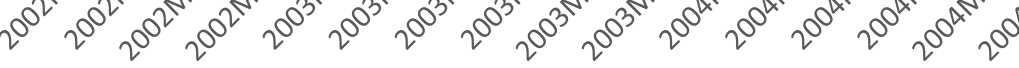

end of month

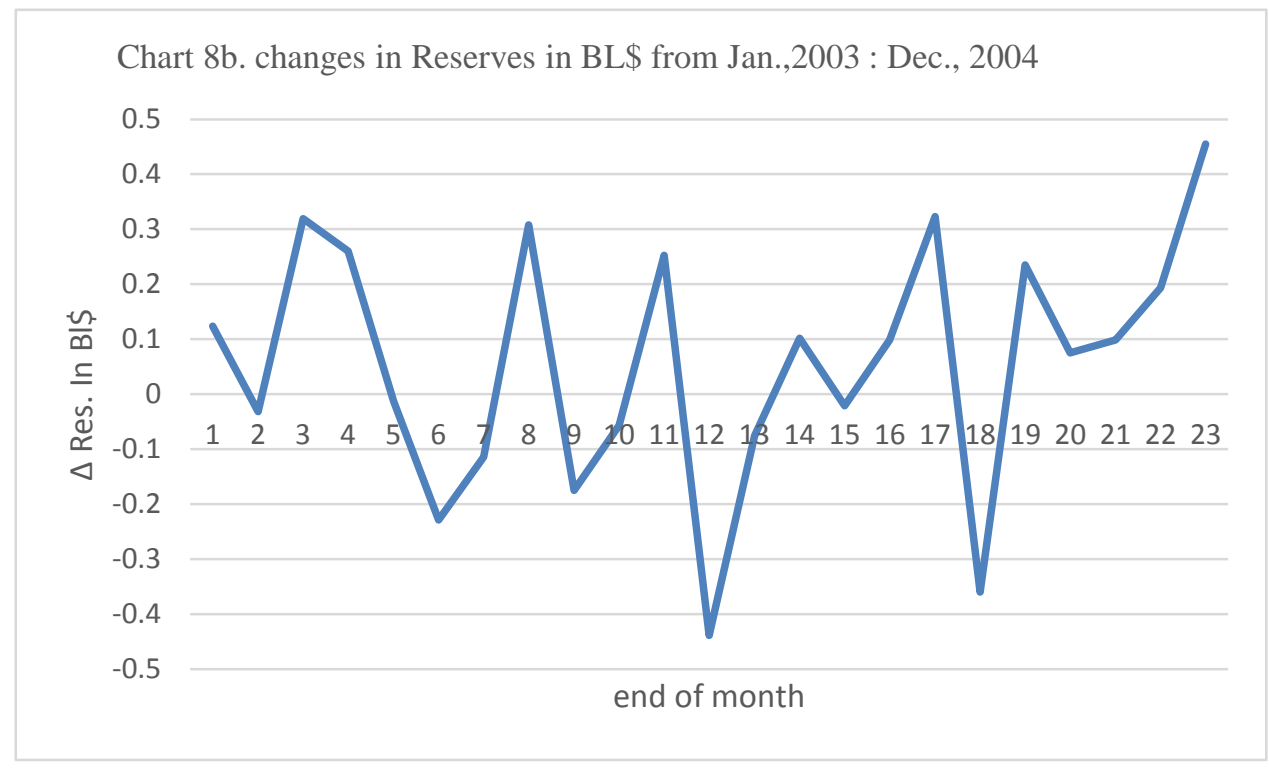

Chart 9. ER per \$ from June,2004: June,2006

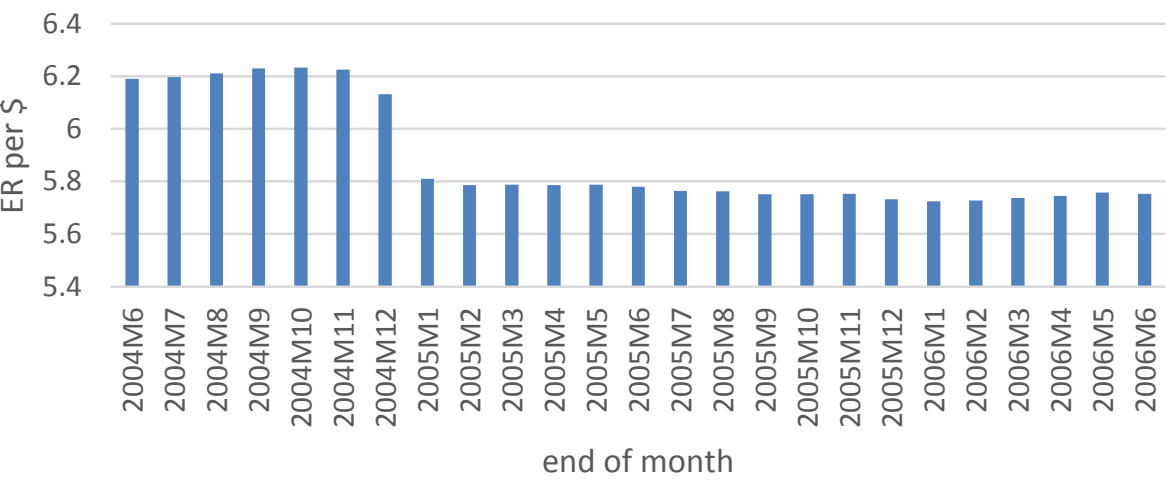



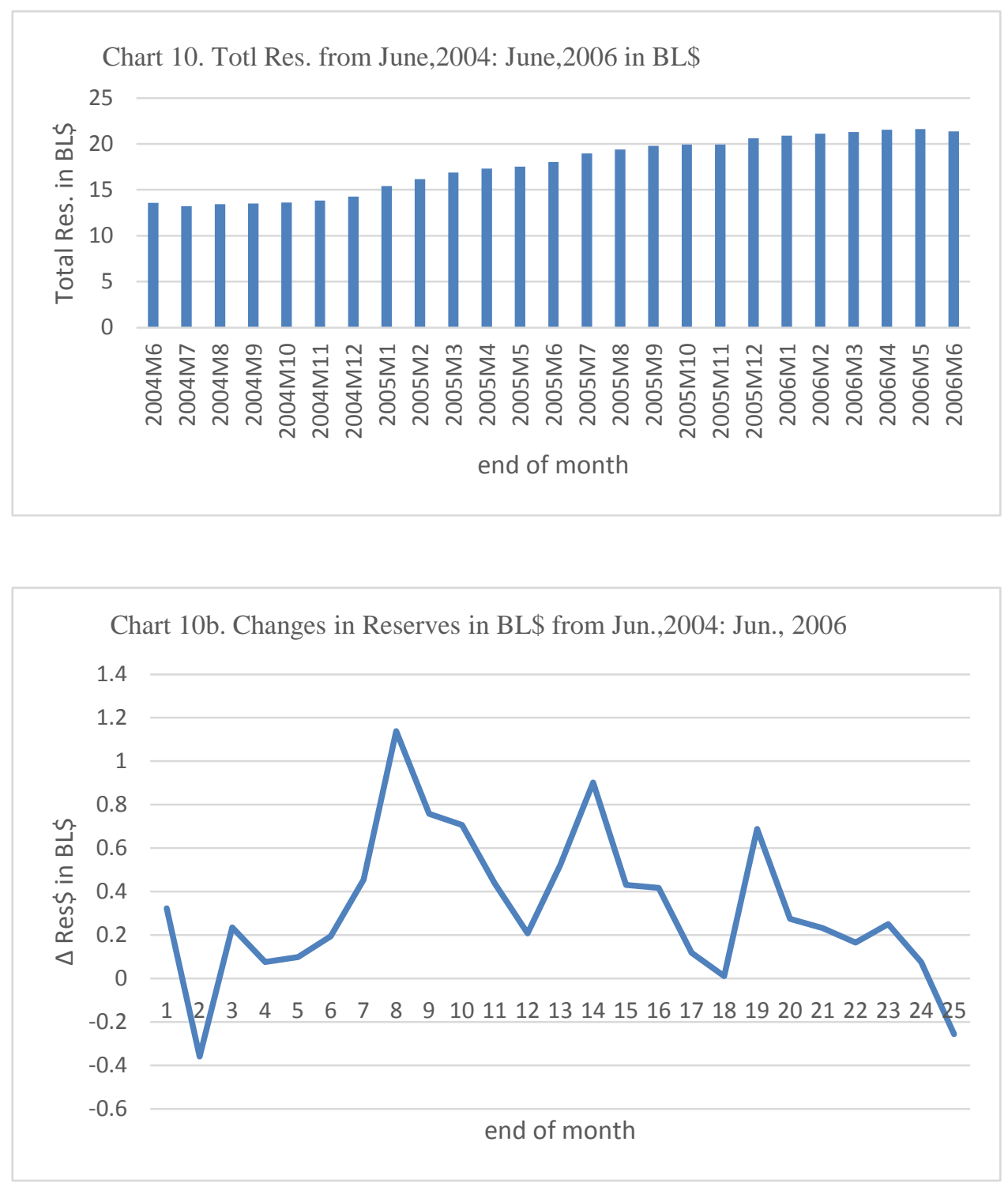

Chart 11. ER per \$ from June,2010 : Sep.,2013

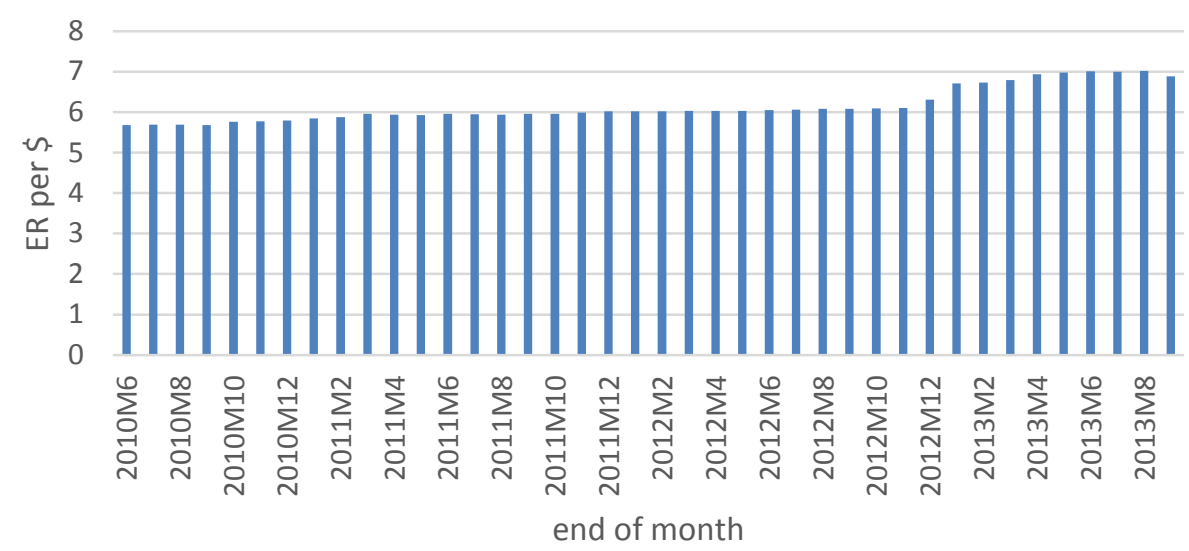



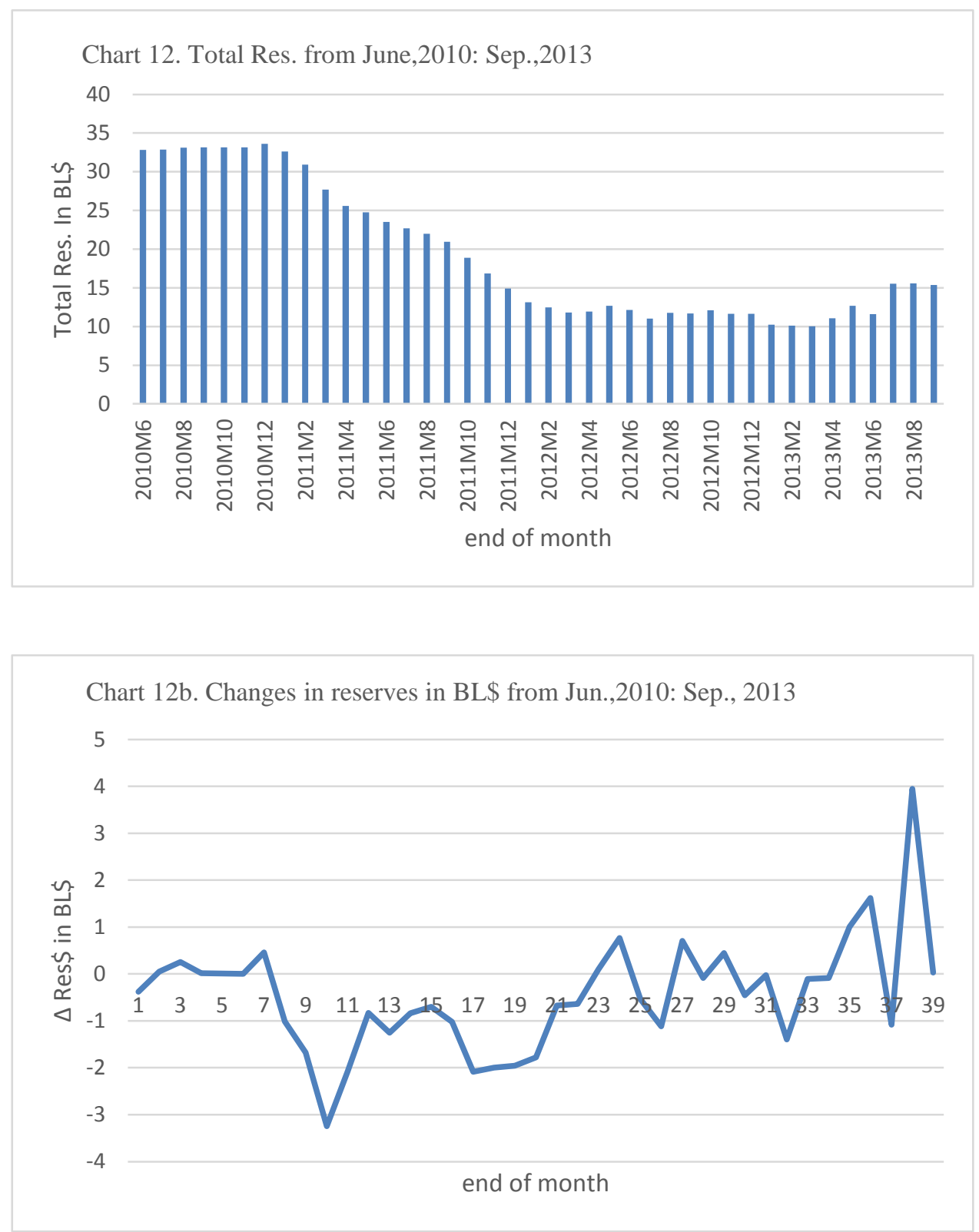

\section{(cc) $\mathrm{BY}$}

This work is licensed under a Creative Commons Attribution 3.0 License. 